\title{
HUMANITY-BASED LEADERSHIP MODEL IN THE GOVERNMENT OF SOUTH SULAWESI PROVINCE (INTEGRATION OF MODERN LEADERSHIP WITH LOCAL WISDOM)
}

\author{
Muhammad Ramli ${ }^{*}$, Sadhriany Pertiwi Saleh ${ }^{2}$ \\ ${ }^{1}$ Department of Political Science, Faculty of Ushuluddin and Philosophy, UIN Alauddin Makassar \\ H.M. Yasin Limpo Street No. 36, Gowa, Indonesia. 90221 \\ *Email: muhammad.ramli@uin-alauddin.ac.id \\ ${ }^{2}$ Department of Communication Studies, Faculty of Dakwah and Communication, UIN Alauddin Makassar \\ H.M. Yasin Limpo Street No. 36, Gowa, Indonesia. 90221
}

\begin{abstract}
This study aims to analyze a collaborative model of modern leadership, namely innovative, transformative and credible with local wisdom by four ethnic cultures, namely Bugis, Makassar, Toraja and Mandar, which in turn will produce officers who prioritize human values in implementing policies based on local wisdom with the philosophy of acca, acca, warani, malempu, and getteng. This research uses qualitative research methods so that the discussion is descriptive. The research was conducted at the South Sulawesi Government Office with four city districts. The research results show that in real terms the human-based leadership model of the Provincial Government of South Sulawesi in its work to improve the welfare of the community with innovative programs and humane services towards advanced governance as the translation of change shows a pretty good trend. Leadership innovation in making change by prioritizing integrity, motivator, ability, experience, honesty, obedience, persistence and intellectuality as a manifestation of the integration of modern leadership and local wisdom as a filter in change so as to lead to an advanced government while still upholding the value of local wisdom as a support which is summarized in Cultured South Sulawesi. Supporting factors that are quite helpful related to the program strategy include the readiness of the apparatus, community involvement and the level of community acceptance, while the inhibiting factors are infrastructure readiness, availability of funds and community readiness to change, but concrete efforts can gradually be overcome so that the strategic program of the South Sulawesi Government as the growth center of the eastern region and the national economic buffer can be realized.
\end{abstract}

Keywords: human-based local wisdom, modern leadership, South Sulawesi

\begin{abstract}
Abstrak: Penelitian ini bertujuan untuk menganalisis model kolaborasi kepemimpinan modern yakni inovatif, transformatif dan kredibel dengan kearifan lokal oleh budaya empat etnis yakni Bugis, Makassar, Toraja dan Mandar yang nantinya akan melahirkan aparat yang mengedepankan nilai kemanusiaan dalam implementasi kebijakan yang berasaskan kearifan lokal dengan filosofi acca, warani, malempu, dan getteng. Penelitian ini menggunakan metode penelitian kualitatif sehingga pembahasannya bersifat deskriptif. Penelitian dilakukan di Kantor Pemerintahan Sulawesi selatan dengan empat kabupaten kota. Hasil penelitian menunjukkan secara riil model kepemimpinan yang berbasis kemanusiaan Pemerintah Provinsi Sulawesi Selatan dalam kiprahnya menyejahterakan masyarakat dengan program inovatif dan pelayanan yang manusiawi menuju pemerintahan yang maju sebagai penjabaran perubahan menunjukkan tren yang cukup bagus. Inovasi pimpinan dalam melakukan perubahan dengan mengedepankan integritas, motivator, kemampuan, pengalaman, kejujuran, kepatuhan, keteguhan dan kecendekiawanan sebagai perwujudan integrasi kepemimpinan modern dan kearifan lokal sebagai filter dalam perubahan sehingga menuju pemerintahan yang maju dengan tetap menjunjung nilai kearifan lokal sebagai penopang yang terangkum dalam Sulawesi Selatan berbudaya. Faktor pendukung yang cukup membantu terkait dengan strategi program di antaranya kesiapan aparatur, keterlibatan masyarakat dan tingkat penerimaan masyarakat, sedangkan faktor penghambat yaitu kesiapan infrastruktur, ketersedian dana dan kesiapan masyarakat untuk berubah, tetapi upaya konkret secara bertahap dapat teratasi sehingga program strategis Pemerintah Sulawesi Selatan sebagai pusat pertumbuhan wilayah timur dan penyangga ekonomi nasional dapat terealisasi.
\end{abstract}

Kata Kunci: kearifan lokal berbasis kemanusiaan, kepemimpinan modern, Sulawesi Selatan

\section{Introduction}

The human situation in modern civilization is a very actual problem, considering that modern humans face dynamics, both concerning economic, political, socio-cultural and religious issues as well as government and social issues. This of course has an impact on human values, especially ethical and moral 
values which ultimately affect the implementation of a government system that leads to Good Governance, Good Clean governance, Sound governance (strong and tough government).

Local wisdom is reflected in local culture, generally contains deep and very philosophical wisdom which has provided inspiration, motivation, creative innovation in facing a life full of dynamics, including work ethic culture, siri' culture, honesty and assertiveness, intelligence, moral ethics in a form of wisdom in leading which of course leads to religious values which are full of human values. In connection with the socio-cultural and political phenomena in responding to government leadership which is full of dynamics and quite complex problems, on the one hand the career advancement of officials, on the other hand the interests of the ruling political party as outlined in public policies that seek to improve the welfare of society often have an impact the non-neutrality of the apparatus in carrying out their duties is the leadership style and behavior of the bureaucratic apparatus in carrying out their duties and responsibilities as public servants.

The crucial problem faced by the government is by prioritizing the concept of democracy which emphasizes direct election of leaders by providing the widest possible opportunity for the community to become leaders without including bureaucracy. The results of democracy produce leadership with leadership duties as bureaucrats, especially in providing public services to the community. Behind the implementation of its leadership, with the emergence of people's views on the low performance of the bureaucratic apparatus, politics dominates the government so that bureaucratic tasks are often taken over by powerful politicians, the bureaucracy is often not neutral because it is depressed by political interests and confused in carrying out its duties and functions so that policies always refer to political orientation causes the interests of society to be neglected. Bureaucratic behavior and leadership which is dominated by politics make strategic policies always benefit the political interests of the rulers and their groups so that whatever is done, on the one hand, is for the image of the government but the substance is political imaging for political interests.

The era of reform and democratization provides nuances and opportunities to give birth to leaders who are rooted and come from below with innovative and transformative nuances as well as transactional through their authority as an autonomous region with creative innovation according to the development and demands of the times without neglecting local culture full of nuances of wisdom as identity and national personality in order to support the performance-based management of the state civil apparatus towards efficient and effective productivity. However, facing quite heavy obstacles with various challenges faced, mainly related to public policies that have implications for public services, are usually overly addressed which leads to the emergence of problems of corruption, gratification, extortion and the like that hit government administrators as services.

The state civil apparatus as the spearhead of government administration is attached to its function as a service function, regulation, development and empowerment function. The reality shows a big challenge for civilization that must be addressed comprehensively, considering that this has become a deep concern for the nation in facing the future, of course, it requires continuous efforts based on social capital which is the substantial values of the nation's civilization which very religious, namely human values. There are several facts in the government bureaucracy, especially in regional governments that public services have not achieved effective results. Public services have not been implemented according to people's expectations because empirically, in their implementation, public services still seem convoluted, slow, expensive, tiring, and in fact they are not transparent and unfair. This shows that the challenges and competition in the future require a true leader who is innovative, credible and charismatic with full wisdom in acting and behaving in developing his leadership mandate by adopting human values.

Globalization requires leadership with social characteristics (Social Leadership), political leadership and states leadership in transforming various inputs from various aspects of the nation's life into efficient and effective administrative policies in bringing people to earthly prosperity. The government program of South Sulawesi Province with ethnic groups framed in four ethnicities, namely Bugis, Bugis Makassar, Mandar and Toraja. South Sulawesi Province with a vision to make South Sulawesi the main pillar of national development and a network of people's welfare, so of course the existing leadership must reach out to four ethnic groups with all their dynamics. Leadership with knowledge of modern leadership 
concepts still requires wisdom in carrying out leadership that is framed in a local culture of four ethnicities so that it gives birth to a human-based leadership model as an integration of modern leadership with local wisdom values.

\section{Materials and Methods}

The research location is the South Sulawesi Provincial Government. The selection of research sites was based on the argument that this institution was responsible for the management of community governance, which of course the leadership aspect was the central point of public services in South Sulawesi Province. This type of research is qualitative research using descriptive analysis. This study uses primary and secondary data. Primary data obtained through in-depth interviews. The focus of a humanitarian-based leadership model by integrating modern government with local wisdom contained in the lontara text. In this study, the concept of humanitarian-based governance will be assessed on the extent to which public services, in this case, are services to the South Sulawesi Provincial Government. Data analysis technique used in this research is a qualitative descriptive technique, which is analyzed using a phenomenological interactive model introduced by Miles \& Huberman (1992) with 3 components of analysis, namely: reduction, data presentation and conclusion.

\section{Result and Discussion}

South Sulawesi has Bugis, Makassar, Toraja and Mandar ethnicities as well as other ethnicities who come from outside South Sulawesi. The four ethnic groups in South Sulawesi and West Sulawesi inhabit different areas, Makassar in the south, Bugis in the middle to the north, Toraja in the far north, and Mandar in the southwest. This ethnic mapping is not necessarily the same as political mapping. Chronologically, there were three large and strong kingdoms in South Sulawesi, namely Luwu, Gowa and Bone.

\section{A. Real Condition of South Sulawesi Leadership}

One of the most important and crucial aspects in determining the progress of an organization or institution, both government and private, is largely determined by the aspect of leadership which is the inspiration and driving force for the institution to achieve goals based on the vision and mission of the institution. Leadership models that are applied variations and are applied by leaders based on willingness. Of course this is inseparable from modern leadership without ignoring the concept of leadership by referring to the cultural roots of the people of South Sulawesi with four ethnicities, namely Bugis, Makassar, Mandar Toraja which are an integrated cultural root and are interrelated in one substance.

In the era of regional autonomy, which brings great consequences to the region, where the authority is getting bigger, as well as the nation's hope to make the government in a standard order, namely good governance with all the elements that are attached, on the one hand the elements of the elections in the era of regional autonomy has implications for the emergence of transactional leadership which often ignores professionalism and competence.

The strategic policy developed by the government of South Sulawesi as a reference in improving the welfare of its people is a strategic program, namely a polite and civilized area which is of course based on local wisdom that upholds human values. The strategic program carried out by the government of South Sulawesi is a manifestation of increasing dignity and self-esteem because shame (Siri) has a high philosophical meaning. The real condition of government leadership in South Sulawesi, where leadership is applied in protecting the society as a whole. This shows that the community has enjoyed quite rapid development with various strategic programs as well as providing greater comfort in providing satisfaction to all levels of society with leadership based on local wisdom which is very humane.

All government innovations are accumulated in strategic policies as the elaboration of the vision and mission that will accelerate the acceleration of development with fundamental changes which will certainly bring South Sulawesi forward based on local wisdom that will improve the welfare of its people through strategic programs affiliated with innovations that are spectacular. Leadership must always improvise the facts faced by society that require effective handling so leadership is very important. Apart 
from adopting the concept of modern leadership, it is also inseparable from the cultural roots that should integrate into a strength.

The success of the South Sulawesi government, which is commanded by the governor, is a figure of an innovative leader which of course cannot be separated from his ability and capability for significant regional planning. This proves that being able to make breakthroughs that are really needed by society makes it very easy for people to improvise to get involved. It is understood that the program that is described as the implementation of the vision and mission is an elaboration of leadership integrity so as to produce significant results and of course based on ability, motivation and what is no less important is the experience in describing programs that have been outlined in the vision and mission of making a world city. However, it cannot be separated from the cultural roots which are manifestations of local wisdom, namely honesty, obedience, persistence and intelligence.

Leadership in South Sulawesi is still heavily influenced by the legacy of past leadership. However, based on the dynamics of development, where science is advancing, of course, mastery of modern leadership concepts becomes a reference in implementing leadership. The concept of past leadership, especially the leadership of the Bugis Makassar, where the kings are descendants, incarnations or intermediaries of the gods. The tightness of the attributes of power and religious attributes shows a very close bond.

Leadership is a cultural factor in delivering a pattern or model into a form of power. In relation to leadership, South Sulawesi is also part of an ethnic pattern of power in which this leadership also fills the historical aspects of the archipelago context and becomes the main values of a culture known to this day. For example, those that most frequently fill Makassar Bugis communication to this day are the cultural values of Alempureng (honesty), Amaccang (intelligence), Asitinajang (propriety), Agettengeng (firmness), Reso (effort) and Siri'(shame). From these values, the Bugis Makassar people bring themselves to be the main self, a self that is attached to the character of being honest, intelligent, proper, firm, working hard and having a sense of shame. These values are then manifested in the leadership of the Makassar Bugis individual, both in the household environment, as well as in the community and institution where the person serves.

From the leadership condition of South Sulawesi, the integrated concept of modern leadership, namely innovative, transformational, credible, which is wrapped in local values that are reflected in local wisdom, is able to overcome various problems in society because it emphasizes human values. The implementation of integrated leadership is still often neglected, given the strong influence of democratic politics, so that the modern leadership concept that prioritizes rationalism and the concept of leadership prioritizes local wisdom with a human-based concept is also often neglected to please people who have contributed to the political process.

\section{B. Social Capital in The Leadership of South Sulawesi}

In principle, development is a community conscious effort to further improve their welfare. However, there needs to be a shared awareness that an impossibility of human development and national development can be carried out in accordance with its mission effectively without involving cultural dimensions, in this case social capital. So a concerted effort is needed to revitalize social capital which enables the birth of a culture of Indonesia's superior human beings.

Social capital is a very powerful development energy. Each social entity not only has a typology but also a configuration of values and norms that largely determine the degree of social cohesiveness and social collaboration in society. This dimension will have a strong influence on the characteristics of people's behavior and the response they show to any development policies made by the government. Whatever plans and projects are designed, it will always be faced with factors, both those that facilitate and prevent them. This is where the role of social capital is crucial.

Francis Fukuyama (1999) argues that social capital plays a very important role in the functioning and strengthening of modern society. Social capital is the sine qua non for human development, economic development, social, political and democratic stability. In it is a cultural component for the life of modern 
society. Weak social capital will dampen the spirit of mutual cooperation, exacerbate poverty, increase unemployment, crime and hinder efforts to improve people's welfare.

In the reform era where Indonesia showed so weak social capital which resulted in the weakening of the superior culture in society and vice versa. As a result, people live as in solitude, insecurity, low spirit of togetherness and confined in a narrow and difficult social group environment. This is what weakens the nation and hinders the various reform efforts that are offered. A nation that has low social capital will always be a nation with an inferior and defeated culture. They have never been taken into account because they will not be able to navigate the competition in various forms of world association.

Social capital is very popular as a development issue that demands careful attention, especially with the emergence of valuable studies from Robert D Putnan (1993, 1995, 2002), France Fukuyama (1999, 2002), James Coleman (1990, 1998), Paul Bullen (2000, 2002), Eva Cox (1995), Cohen and Prusak (2001). Adam Smith in the 18th century in their economic studies has included elements of social capital very clearly, that is, they call it a social contract, civil society that will determine the progress of economic development. There are several steps and strategic goals for social capital development. These targets include, among others, religion, culture, education, security, socialization of new values and through various direct development policies, especially those related to policies for public welfare. To achieve this culture of excellence, a strong commitment is needed, namely a strong collective will. This is done with various strategies, namely strong motivation to realize the reality of implementation by implementing agreed values. There is a strong role model from the leader.

\section{Leadership Innovation of South Sulawesi}

The leadership innovation of Bugis Makassar, Toraja and Mandar is related to the ability of the Makassar Bugis elite to metamorphose in the development of the government sector with various elements of knowledge, symbols, power and money in maintaining and or reproducing leadership innovation in the course of the power space. The role of symbols, power and money in each phase of elite formation within the Bugis Bone and Makassar Gowa ethnic groups took place fluctuatively. In a certain phase, the elite is formed at the same time by symbol, power and money. But at other times, it may only be one or two of these three factors.

1. Leadership Concept of Bugis-Makassar

The formation of the elite in the Bugis and Makassar ethnic groups that occurred in the traditional phase took place with the use of very strong symbols. The most prominent use of symbols begins with the concept of tomanurung and then strengthens with other symbols such as gaukang and kalompoang. These concepts leads to the formation and strengthening of the elite position, which is expected to become a trigger for peace and prosperity in social life. Referring to the symbols raised by the Bugis and Makassar ethnic groups, which started with the concept of power and the way of life in society, it is seen that the Bugis and Makassar ethnic groups both want the pattern of relations between the rulers and those controlled to be contractual. Although symbolically the community gives great authority to its leader, but at the same time, the leader must obey the agreement given by the tomanurung symbol giver.

Based on the concept of its arrival, the concept of the tomanurung symbol is estimated to be the design result of the elites of each community group who experience group management problems that cause conflict between them. To avoid conflicts that are detrimental to the elite of this group, they need strong leaders who unite their differences. The cultural value of the Makassar Bugis Ethnicity based on the client's Patron concept proves that the leadership path is still at the Ajjoareng and Joa stages, for example the appointment of the head of the service by the appointed leader based on Joa or his subordinates or closest people.

\section{Leadership Concept of the Toraja (To-Raja) People}

This can very clearly be seen in the leadership model in this area. As a real example, it can be witnessed in the face of the South Sulawesi Governor's leadership for two periods (ten years), Syahrul Yasin Limpo. According to him, during his ten years of leadership in this region, the governmental paradigm he used was Siri 'na Pacce. This value is the spirit of governing. In his writing, he quoted the 
philosophy of the Makassar government that; The dignity of the people is in the government, the form and implementation of development is in the will of the people, so reflect on them, because it never lies.

The concept of leadership in South Sulawesi appears not only to exist in Bugis and Makassar culture, but also to be found in Toraja and Mandar societies. In Tojara, the term siri' is the same as Longko'. According to Disk Sasmanto Pasande, longko' is an understanding that is firmly held by Toraja society, not only contains values of honor, self-respect and shame but also other positive values in the form of enthusiasm and work ethic. The concept of leadership that must be reflected in the life of the Toraja people include: (1) Longko' (Siri', self-esteem, tolerance); (2) Kamalamburan (honesty); and (3) Karapasan (harmony).

3. Leadership Concept of Mandar People

The concept of leadership that is upheld by the Mandar people includes: (1). Malaqbiq (charismatic)the nature of malaqbiq is reflected in five things, namely: honest and fearful, telling the truth and being vigilant, intellect and holy intention, courageous and resolute. People who have the malaqbiq attitude are considered to have become human; (2) Amalappuang (honesty)-honesty is a value that must be upheld by a leader. Honesty is the source of all values of goodness so if a leader has been honestly heeded, it can be ascertained that the leader's morale has been destroyed; (3) Sipakaraya (gentle)-the value of sipakaraya (mutual respect) between the leader and the community will be created well if the love shown by the leader to the community can be increased.

Changes made in an area require comprehensive and integrated handling in various aspects, both aspects of the apparatus as government administrators as well as policy makers and the community as policy targets, of course it requires a touch of leadership that is able to drive all aspects of change, especially in the implementation of strategic policies that will be carried out. Leadership becomes a benchmark in the success of strategic policy implementation so that it requires a leadership model that has an established strategic role in carrying out its function to control the organization. The application of innovative leadership based on humanity in the implementation of strategic policies by adopting theory of Edward III in the implementation of public policies shows that there are factors that influence policy implementation, including communication, resources, disposition, and bureaucratic structures as strengthening in strategic policy implementation.

\section{Determinant Factors in The Application of Leadership Models with The Integration of Cultural Wisdom and Modern Leadership on The Implementation of Strategic Policies}

Support for a policy is very important because the dynamics in its implementation of the problems faced are quite varied, so it needs several supporting factors, namely apparatus resources, community involvement, level of community acceptance, while factors that can hinder are infrastructure readiness, willingness of supporting funds and community readiness to change. Strategic program innovation requires an accurate strategy in facilitating the running of government programs, especially in bringing people to be prosperous. Modern leadership is a leadership model that always leads to the birth of new innovations to find solutions to society's problems with social facts. One solution is the emergence of a strategic government policy with three strategic goals, namely reconstructing the fate of the people to be prosperous and comfortable, restoring environmental order and carrying out bureaucratic reforms that will produce quality services so that of course human-based with the integration of cultural root values.

Supporting factors in the implementation of strategic policies as a description of innovative leadership are quite varied, although they are still limited, but with the strategic program, the public is more sympathetic to government programs, marked by direct involvement in the implementation of the development program. Community empowerment is a significant supporting factor. Meanwhile, the inhibiting factor for government programs, both in opposing the program and unwilling to participate in the implementation of development programs. However, the government efforts can gradually be overcome. Innovative leadership touches are able to overcome obstacles even though they are not maximized.

The integration of modern leadership and local wisdom is a leadership model that is suitable to be applied, considering that leadership is based on humanity which greatly elevates human dignity. This is a 
new and spectacular step in bringing South Sulawesi Province to become developed regions that elevate the dignity of society with significant progress that has been made in the past, namely as transit ports and world trade airports.

\section{Conclusion}

The real condition of leadership is a cultural factor in delivering a pattern or model into a form of power. The relationship with the leadership of the Bugis Makassar, Mandar and Toraja is part of the ethnic power pattern where this leadership also fills the historical aspects of the archipelago context and becomes the main values. Bugis Makassar, Toraja and Mandar communication is a cultural value in the form of honesty, intelligence, decency, determination, effort and shame. These values are then manifested in the leadership model. In the context of modernity, it is reflected in the innovative, transformational and credible leadership that is integrated and patterned with cultural wisdom to become a model for the leadership of the South Sulawesi government, even though it is still facing obstacles in the political democracy situation which requires transactional leadership. Social capital has always been a means of unifier and reference in leadership because it is an application of the main elements of social capital, namely; participation in a network; reciprocity; trust or sense of trust; values of social norms and proactive action. Leadership innovation from Bugis, Makassar, Mandar and Toraja is an elaboration of modern leadership concepts and cultural wisdom that is able to give birth a leadership model that always creates innovations that can bring fundamental changes towards achieving the vision and mission as the great hope of society. One of the determinants of the achievement of the vision and mission is the aspect of leadership, where the leadership of the South Sulawesi government in driving development still refers to integrity, motivation, ability, experience, honesty, obedience, persistence and intelligence as a translation of local wisdom so that development towards change continues to advance humanity. From the aspect of leadership where the supporting and inhibiting factors become integrated, it has brought South Sulawesi to experience significant progress. Obstacles and challenges, especially political support, are still lacking, in addition to the inadequate infrastructure aspect due to very limited readiness, insufficient availability of funds, but gradually they can be resolved with higher levels of community participation.

\section{References}

Abdullah, Hamid. 1985. "Manusia Bugis Makassar: Suatu Tinjauan Historis terhadap Pola Tingkah Laku dan Pandangan Manusia Bugis Makassar." Jakarta: Inti Idayu Press.

Amir, Muhammad. 2014. “Gerakan Mara’dia Tokape di Mandar 1870-1873.” Makassar: De La Macca.

Azizy, A. Qadry. 2007. "Change Management Dalam Reformasi Birokrasi.” Jakarta: Gramedia Pustaka Utama.

Balandier, Geogres. 1972 "Religion and Power," in Political Antropology. London: Penguin Books.

Barata, Atep Adya. 2004. "Dasar-Dasar Pelayanan Prima: Persiapan Membangun Budaya Pelayanan Prima untuk Meningkatkan Kepuasan dan Loyalitas Pelanggan.” Jakarta: PT. Elex Media Komputindo.

Bartol, Kathryn M. 1995. "Management A Pacific Rim Focus.” Sydney: Mc GrawHill Book Company.

Bass, B.M., and Avolio, B.J. 1994. "Improving Organizational Effectiveness through Transformational Leadership." Thousand Oaks: Sage Publications Inc.

Bennis, W.G., and Nanus, B. 1995. "Leaders: The Strategies for Taking Charge." New York: Harper and Row.

Bennis, Warren. 1989. “Menjadi Pemimpin Yang Efektif,” in Becaming a Leader. Translated by Anna W. Bangun, 1994. Jakarta: PT. Elex Media Komputindo.

Brown, Michel. E, 1997. "Government Policies and Ethnic Relation in Asia And Pasific.” London: The Mit Press.

Conger, Jay. A. 1997. "Pemimpin Karismatik," Translated by Anton. Jakarta: Binarupa Aksara.

Creswell, John W. 1994. "Research Design: Qualitatif \& Quantitatif Approaches.” California: Sage Publications Inc.

Denhardt, Janet V., and Robert B. Denhardt. 2003. “The New Publik Service: Serving, not Steering.” London: M. E. Sharpe Inc.

Dvorin, Eugene. P., and Simon, Robert. H. 2000. "Dari Amoral Sampai Birokrasi Humanisme.” Jakarta: Penerbit Prestasi Pustaka Karya.

Edward. 1980. "Implementing Public Policy," in Policy Implementation and Bureacracy. Andal. B. Ripley., and Grace A. Franklin, New York: The Dorsey Press.

Fahmal, Muin. 2006. "Peran Asas-Asas Umum Pemerintahan yang Layak dalam Mewujudkan Pemerintahan yang bersih." Yogyakarta: Penerbit UII Press.

Fibrianti, Nurul. 2014. Analisis Gaya Kepemimpinan dalam Perspektif Budaya Mandar di Kabupatern Polewali Mandar. Bachelor Thesis. Universitas Hasanuddin. 
Haris, Syamsuddin., Asosiasi Ilmu Politik Indonesia (AIPI)., and Partnership for Governance Reform in Indonesia (PGRI). 2005. "Desentralisasi dan Otonomi Daerah, Desentralisasi, Demokratisasi dan Akuntabilitas Pemerintahan Daerah." Jakarta: LIPI Press.

Hasbullah, Jousairi. 2006. “Social Capital, Menuju Keunggulan Budaya Manusia Indonesia.” Jakarta: MR. United Press.

Hughes, Owen E. 1994. "Public Management and Administration: An Introduction." New York: St Matius Press.

Ibrahim, Anwar. 2003. "Sulasena, Kumpulan Esai tentang Demokrasi dan Kearifan Lokal.” Makassar: Lephas Unhas.

J. Cooper, Phillip. 1998. "Public Administration for The Twenty-First Century." USA: Harcourt Brace College Publishers.

James O'Toole. 1999. "Leadership A to Z: A Quide for The Appropriately Ambition (Panduan Berambisi Secara Positif," translated by Neneng. Jakarta: Erlangga.

Kartdirdjo, Sartono. 1984. "Kepemimpinan dalam Dimensi Sosial.” Jakarta: LP3ES.

Keban, Yeremias T. 2008. "Enam Dimensi Strategis Administrasi Publik (Konsep, Teori dan Isu)." Yokyakarta: Gava Media.

Locke, E.A. 1997. "The Essence of Leadership: The Four Keys to Leading Successfully.” New York: Lexington Books.

Marzuki, Laica. 1995. "Siri' Bagian Kesadaran Hukum Rakyat Bugis-Makassar.” Ujung Pandang: Hasanuddin University Press.

Mattulada. 1985. "La Toa, Suatu Lukisan terhadap Antropologi Politik Orang Makassar.” Jakarta: UGM Press.

Maxwell, John.C. 1995. "Mengembangkan Kepemimpinan di Dalam Diri Anda," Translated by Anton. Jakarta: Binarupa Aksara.

Mujahid, Imam Fahmid. 2012, Identitas Dalam Kekuasaan.” Makassar: Ininnawa.

Nirwana, Andi. 2018. Local Religion; To Wani To Lotang, Patuntung dan Aluk To Dolo di Sulawesi Selatan.” Bandung: Bahasa \& Sastra Arab UIN Sunan Gunung Djati.

Pasande, Diks Sasmanto. 2013. "Budaya Longko Toraja dalam Perspektif Etika Lawrence Kohlberg." Jurnal filasafat 23(2): 117-133.

Perlas, Christian. 2006. "Manusia Bugis.” Jakarta: Forum Jakarta-Paris, Ecok Francaise d'Extreme-orient.

Poltak Sinambella, Lijan et al. 2006. "Reformasi Pelayanan Publik, Teori, Kebijakan dan Implementasi." Jakarta: Bumi Aksara.

Posner, Kouzes. 2004. "Leadership The Challenge, Tantangan Kepemimpinan.” J a k a rta: Erlangga.

Putra, Shrim Heddy Ahimsa. 2007. "Patron dan Klien di Sulawesi Selatan." Yogyakarta: Kepel Press.

Rahim, Rahman. 1992. "Nilai-Nilai Utama Kebudayaan Bugis.” Ujung Pandang: Lephas Unhas.

Rivai, Veithzal. 2003. "Kepemimpinan dan Perilaku Organisasi.” Jakarta: Rajagrafindo.

Sedarmayanti. 2003. "Good Governance dalam Rangka Otonomi Daerah.” Bandung: Mandar Maju.

Sultra, Ahmad Rustan. 2018. Pola Komunikasi Orang Bugis Kompromi antara Islam dan Budaya.” Jogjakarta: Pustaka Pelajar.

Vincent Caspersz. 1994. “Manajemen Pelayanan Kualitas Total Cara Terbaik untuk Memuaskan Pelanggan.” Jakarta: Gramedia.

Yukl, Gary. 1998. “Kepemimpinan dalam Organisasi,” Translated by Yusuf. Jakarta: Prentice-Hall-Inc. 